\title{
Improving the Sensitivity of Electrode-Separated Piezoelectric Quartz Crystal Sensor for Copper(II) Ions by Immobilization of the N-2-Aminoethyl-3-Aminopropylsilane Group
}

\author{
Dosil P. de Jesus, Carlos A. Neves and Claudimir L. do Lago* \\ Departamento de Química Fundamental, Instituto de Química, Universidade de São Paulo, \\ Av. Prof. Lineu Prestes 748, 05508-901, São Paulo - SP - Brazil
}

\begin{abstract}
Um sensor a cristal piezelétrico de quartzo com eletrodos separados e superfície quimicamente modificada foi proposto. A silanização com N-2-aminoetil-3-aminopropiltrimetoxisilano permitiu a imobilização do grupo N-2-aminoetil-3-aminopropilsilano sobre a superfície de um cristal de quartzo de 3,5 MHz. Uma cela em fluxo foi fabricada em poli(metacrilato de metila) com dois eletrodos de latão. Nesta cela, a solução entra em contato somente com um lado do cristal e o eletrodo é recoberto com um filme de poliéster, prevenindo assim a corrosão do eletrodo. Esta inovação reduz o custo da cela e proporciona o desacoplamento DC. O cristal modificado mostrouse mais sensível a íons cobre (II) do que a magnésio(II), níquel(II), zinco(II) e cobalto(II). Para injeções de $100 \mu \mathrm{L}$ de amostra, o limite de detecção para cobre(II) foi de $6 \mu \mathrm{mol} \mathrm{L}^{-1}$ que é um resultado significativo comparado com aqueles obtidos com cristal não modificado.
\end{abstract}

An electrode-separated piezoelectric quartz crystal sensor with a chemically modified surface was proposed. The modification was carried out by a silanization procedure with $\mathrm{N}$-2-aminoethyl3-aminopropyltrimethoxysilane, yielding the immobilised N-2-aminoethyl-3-aminopropylsilane group over the surface of a $3.5 \mathrm{MHz}$ piezoelectric quartz crystal. A flow cell was manufactured with poly(methyl methacrylate) and brass, instead of noble metals, for the electrodes. In this cell, the solution touches only one side of the crystal and the related electrode is coated with a polyester film, which prevents corrosion and does not disturb the oscillation process. This innovation reduces the cost of the cell and renders an electronics non DC-coupled to the solution. The modified crystal proved to be more sensitive to copper(II) ions than magnesium(II), nickel(II), zinc(II), and cobalt(II). For $100 \mu \mathrm{L}$ sample injections, the limit of detection for copper(II) was $6 \mu \mathrm{mol} \mathrm{L}^{-1}$, which is an impressive result when compared with that for an unmodified crystal.

Keywords: electrode-separated piezoelectric sensor, silanization, flow injection analysis, QCM, N-2-aminoethyl-3-aminopropyltrimethoxysilane

\section{Introduction}

Although most applications of quartz crystal microbalance use piezoelectric quartz crystal (PQC) with metallic electrodes deposited over its faces, the contact between the electrode and the surface is not absolutely necessary. A gap between the electrode and the crystal surface represents a capacitive contribution to the equivalent circuit of the PQC. If the gap is small enough, this serial capacitance is high and does not prevent the oscillation process of the $\mathrm{PQC}$ in an electronic oscillator.

Slutsky and Wade ${ }^{1}$ used an electrode-separated piezoelectric quartz crystal (ESPC) to study the adsorption of hexane and argon on the quartz surface. This mode of

\footnotetext{
*e-mail: claudemi@iq.usp.br
}

operation was not used for analytical purposes for three decades, until Nomura et $a l .^{2}$ decided to fill the gap with a liquid. They observed that the oscillation frequency varied with the permittivity and conductivity of the liquid in addition to the density, viscosity, and mass deposition effects noticed for normal PQC. Other works dealing with applications and characterization of the ESPC have been published $^{3-7}$. Although the oscillation frequency is changed by all the above properties, some approaches use variations of the bulk of the liquid ${ }^{3-6}$, mass deposition on the crystal surface $^{10-16}$, or both ${ }^{17}$.

Nomura et al. ${ }^{10}$ described the application of an ESPC to adsorb hydroxo metal ions instead of free metal ions, because the silanol group from the crystal surface is a better complexing site for the former species. The hydroxo ions are formed by adjusting the $\mathrm{pH}$ before the sample is 
introduced in the cell. However, this procedure has a draw back: the aging of the hydroxo compounds reduces the frequency change because more hydroxide is formed, which is not effectively retained by the crystal surface. Thus the standing time before injection is an important parameter and must be strictly controlled.

Usage of coatings is very common in normal-PQC applications in order to increase the sensitivity or selectivity of the analytes to be adsorbed on the crystal surface. However in the works cited above, the chemical modification of the surface of the crystal was not employed. The absence of works using this approach seems particularly curious because the silanization of the silica surface - and thus, of the quartz surface - is a well-known technique. In addition to the increase of sensitivity or selectivity, the chemical modification has the advantage of preventing the loss of the coating material due to the covalent bonds that anchor the groups of interest to the surface.

In the present work, we introduce the chemical modification of the ESPC, by using an amino-group silanization reagent, and the use of a polymer-coated electrode to prevent corrosion and DC-coupling. Although other reagents have been used in our laboratory, in this paper the enhancement of sensitivity for copper(II) ion by surface modification with N-2-aminoethyl-3-aminopropyltrimethoxysilane (AEAPTS) is reported. AEAPTS and other reagents for immobilization of amino groups have been used before for surface modification of normal-PQC ${ }^{18-24}$ and surface acoustic wave (SAW) ${ }^{25}$. However, these devices have electrodes over the surface to be modified.

\section{Experimental}

\section{Apparatus}

The PQC was obtained from a commercial electronic component (ABC-Xtal Microeletrônica, Rio de Janeiro, Brazil) with $3.579545 \mathrm{MHz}$ series resonance frequency. This PQC is easy to find because it is commonly used in color TV circuit. The 12-mm diameter and $0.5-\mathrm{mm}$ thickness crystal was removed from the metallic case and the silver electrodes were eliminated by using nitric acid. The cell (Figure 1) was made of poly(methyl methacrylate) (PMMA) with two movable brass electrodes. The gap between one of the electrodes and the crystal is about 0.2 $\mathrm{mm}$ and filled with air. The other gap is $0.1 \mathrm{~mm}$ and filled with the solution. Thus the electrode surface must be protected against corrosion. This is achieved by using a $15-\mu \mathrm{m}$ thickness polyester film obtained from a $2.2 \mu \mathrm{F}$ and 250 V capacitor (Philips, São Paulo, Brazil). The plastic package of the capacitor was removed, resulting in two aluminized polyester tapes. Before the usage of the film as a protective coating for the electrode, the aluminium was eliminated by nitric acid. The brass electrode was wrapped in the film and pressed against the PMMA support, resulting in a smooth sheet of polyester without air bubbles between the surfaces of polymer and metal. The other electrode was not protected with the polyester film because the solution does not touch this side of the cell.

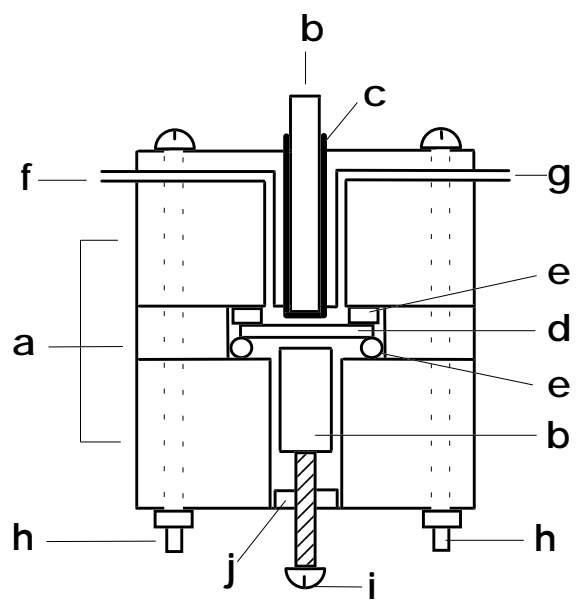

Figure 1. Flow cell diagram: (a) PMMA blocks, (b) electrode, (c) polyester film, (d) PQC, (e) o-ring, (f) solution inlet, (g) solution outlet, (h) assembly bolts, (i) screw and (j) nut for electrode positioning.

The oscillator circuit is based on a TTL hex-inverter integrated circuit 74VHCU04N (National Semiconductor, Santa Clara, CA), which is an optimized version for oscillator implementations. An HP 3458A multimeter (Hewlett Packard, Palo Alto, CA) interfaced to a Pentium $60 \mathrm{MHz}$ microcomputer was used for data acquisition. An HP 4194A Impedance/Gain-Phase Analyzer (Hewlett Packard, Palo Alto, CA) was used for the characterization of the PQC.

Figure 2 shows a diagram of the system. A peristaltic pump MS Reglo (Ismatec, Switzerland) supplied with Tygon (inner diameter $2.06 \mathrm{~mm}$ ) pump tubing was used for propulsion of the fluids to the cell. The samples were injected through a manual valve (CENA, Piracicaba, São Paulo, Brazil) with a $100-\mu \mathrm{L}$ loop. The carrier and samples solutions were placed in a water bath at $25^{\circ} \mathrm{C}$.

Glucose aqueous solutions from 2 to $20 \% \mathrm{~m} / \mathrm{v}$ and deionized water were used to evaluate the viscosity and density effect over the frequency of oscillation. Conductivity effect was evaluated with deionized water and $\mathrm{KCl}$ aqueous solutions from $10^{-6}$ to $1.0 \mathrm{~mol} \mathrm{~L}^{-1}$.

\section{Reagents}

All chemicals were of analytical grade. The solutions were prepared with deionized water Nanopure (Barnstead 


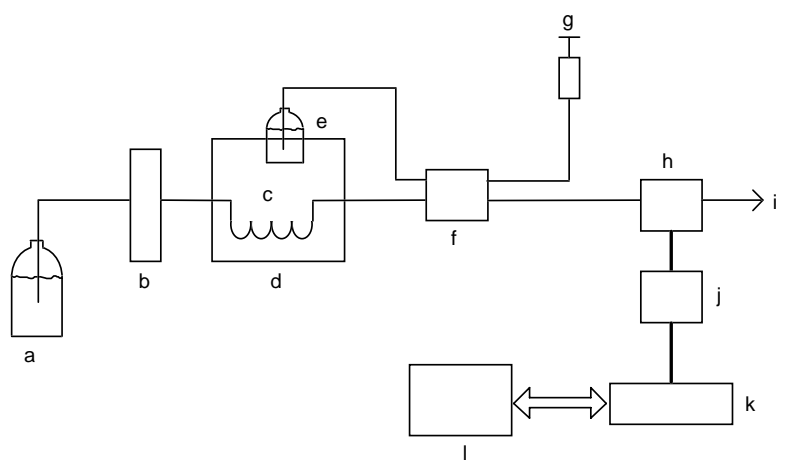

Figure 2. Schematic diagram of the system: (a) carrier reservoir, (b) peristaltic pump, (c) coil, (d) water bath, (e) sample reservoir, (f) injector, (g) syringe, (h) detection cell, (i) waste, (j) oscillator circuit, (k) frequency counter, and (i) microcomputer.

Thermolyne, Dubuque, IA). The silanization was carried out with AEAPTS (Pierce, Rockford, IL). Methanol, toluene, and chloroform (Labsynth, Diadema, Brazil) were used to wash the modified PQC.

\section{Surface modification}

Before modification, the PQC surface was activated by $\mathrm{HCl}$ aqueous solution $(1: 1 \mathrm{v} / \mathrm{v})$ for $24 \mathrm{~h}$ at room temperature. After washing with deionized water, the PQC was dried at low pressure in a vacuum oven at $80^{\circ} \mathrm{C}$. Surface modification was obtained by dipping the PQC in AEAPTS solution for 30 min under stirring and in a closed vessel. This solution was prepared with $0.1 \mathrm{~mL}$ of AEAPTS and $5 \mathrm{~mL}$ of anhydrous toluene. After the silanization, the PQC was washed successively with toluene, chloroform, and methanol. The cure was completed at $80^{\circ} \mathrm{C}$ for $24 \mathrm{~h}$. Before use, the modified PQC required a conditioning step, which comprised of about $30 \mathrm{~min}$ washing with electrolyte at flow rate of $0.5 \mathrm{~mL} \mathrm{~min}^{-1}$.

\section{Adsorption of metal ions}

The experiments about metal ion adsorption were carried out by injection of a $100 \mu \mathrm{L}$ sample solution followed by injection of the same volume of $50 \mathrm{mmol} \mathrm{L}^{-1}$ EDTA ( $\mathrm{pH}$ 8.0) to remove the complexed metal ion. The carrier was $0.1 \mathrm{~mol} \mathrm{~L}^{-1} \mathrm{KNO}_{3}$ at flow rate of $1.1 \mathrm{~mL} \mathrm{~min}^{-1}$. The $\mathrm{pH}$ of the solutions was adjusted with $\mathrm{KOH}$ or $\mathrm{HNO}_{3}$. The carrier solution was bubbled with nitrogen to prevent $\mathrm{CO}_{2}$ absorption, which could change the $\mathrm{pH}$, because the solution was not buffered. To prevent significant conductivity changes, all metal solutions were prepared in $0.1 \mathrm{~mol} \mathrm{~L}^{-1} \mathrm{KNO}_{3}$.

\section{Results and Discussion}

The cell was used for several months with solutions ranging from $\mathrm{pH} 2$ to 10 without visible evidence of corrosion of the brass electrode or degradation of the polyester film. However, the cell was not exposed to strong oxidant solutions.

Figure 3 shows the frequency shift due to the conductivity of the carrier solution. The frequency shift is almost stable at low conductivities, which is a desirable situation for studies about adsorption on the PQC surface. However, low conductivity is obtained for low concentration of ionic species, which is not practical. Another stable region is observed from 0.003 to $0.013 \mathrm{~S}$ $\mathrm{cm}^{-1}$, which corresponds to 0.02 to $0.1 \mathrm{~mol} \mathrm{~L}^{-1} \mathrm{KCl}$.

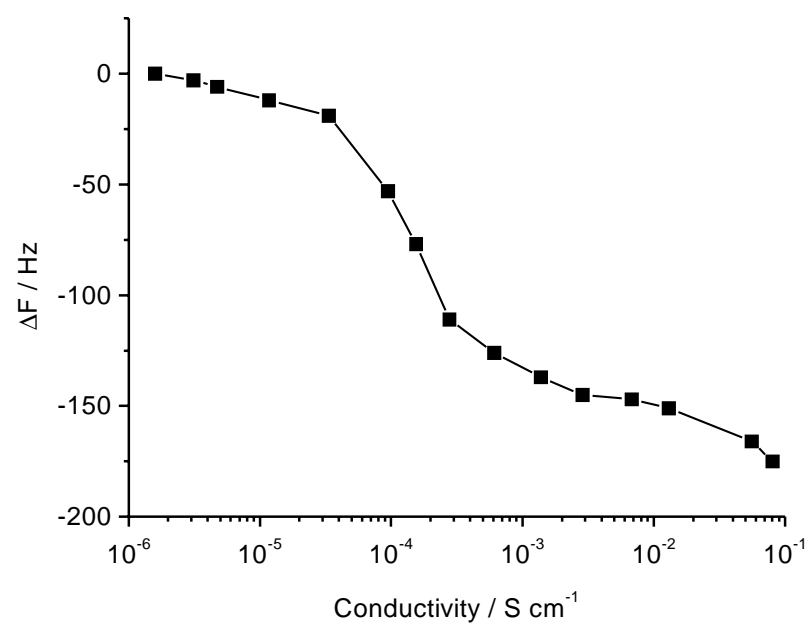

Figure 3. Frequency shift versus conductivity of the carrier solutions $\left(0.1 \mathrm{~mol} \mathrm{~L}^{-1} \mathrm{KCl}\right)$. Flow rate, $2 \mathrm{~mL} \mathrm{~min}^{-1}$.

A buffer solution was not used to prevent the formation of complexes and precipitates containing the metal ions and some species from the buffer, which could obscure the actual complex capacity of the N-2-aminoethyl-3aminopropylsilane (AEAPS) group. Thus, the studies were performed with $\mathrm{KCl}$ solutions for conductivity effect evaluation and $\mathrm{pH}$-adjusted $\mathrm{KNO}_{3}$ solution as the carrier for metal ion samples to prevent complex formation with chloride ions.

The frequency shift varies linearly with $(\rho \eta)^{1 / 2}$, shown intercept $(710 \pm 13) \mathrm{Hz}$, slope $(-759 \pm 11) \mathrm{Hz} \mathrm{mL}^{1 / 2} \mathrm{~g}^{-1 / 2}$ $\mathrm{cP}^{-1 / 2}$, standard deviation of the regression $3.8 \mathrm{~Hz}$, and correlation coefficient -0.9991 for 10 data points. Although the frequency shift varies linearly with $(\rho \eta)^{1 / 2}$ as predicted by the Gordon-Kanazawa's equation ${ }^{26}$, the slope does not agree with the one obtained by this equation. The slope is larger than that of the normal PQC by a factor of about 1.4 , which agrees with the 1.5 factor obtained by Dazhong et al. ${ }^{16}$ for other ESPC system. Since temperature greatly affects the viscosity, it is important to evaluate this effect over the baseline. Taking into account the viscosity and density from water at 25 and $26^{\circ} \mathrm{C}$ and above data, 
one can conclude that this $1{ }^{\circ} \mathrm{C}$ change alters the frequency by approx. $9 \mathrm{~Hz}$, which is a significant value. Thus, the temperature must be controlled to prevent fast variations of temperature in this range. Our experience shows that a water bath (item d in Figure 2) and an air-conditioned room are enough to obtain good results. Although temperature also affects the conductivity, this effect is negligible because the system operates in a stable region of conductivity as pointed out (Figure 3).

We proposed the cell equivalent circuit shown in Figure 4. The components $\mathrm{C}_{0}, \mathrm{R}_{\mathrm{q}}, \mathrm{C}_{\mathrm{q}}$, and $\mathrm{L}_{\mathrm{q}}$ stand for the piezoelectric crystal. The capacitance $\mathrm{C}_{3}$ stands for the gap filled with air. The gap with solution is represented by the components $\mathrm{C}_{2}$ and $\mathrm{R}_{1}$. The polyester film is represented by $\mathrm{C}_{1}$. The approximate values assigned to $\mathrm{C}_{0}, \mathrm{C}_{1}, \mathrm{C}_{2}, \mathrm{C}_{3}$, and $\mathrm{R}_{1}$ were obtained by taking into account the geometry and composition of the materials. The values assigned to $\mathrm{R}_{\mathrm{q}}, \mathrm{C}_{\mathrm{q}}$, and $\mathrm{L}_{\mathrm{q}}$ were obtained from the original $\mathrm{PQC}$ with the impedance analyzer. To calculate the capacitance $\mathrm{C}_{2}$, the gap was considered to be filled with water that is the situation when this is the most important path, since the resistance $\mathrm{R}_{1}$ is high. On the other hand, for practical situations $\left(0.1 \mathrm{~mol} \mathrm{~L}^{-1} \mathrm{KCl}\right), \mathrm{R}_{1}$ is the most important path for electronic conduction.

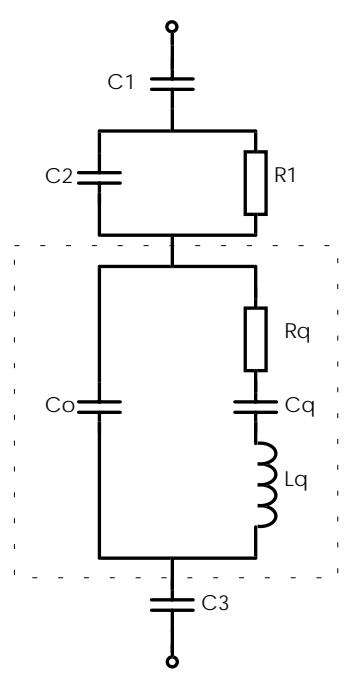

Figure 4. Equivalent circuit of the cell. The approximated values of the components and respective reactance at series resonance frequency $(3.58 \mathrm{MHz})$ are $\mathrm{C}_{1}=70 \mathrm{pF}(-650 \Omega), \mathrm{C}_{2}=200 \mathrm{pF}$ $(-230 \Omega), \mathrm{R}_{1}=3.0 \Omega, \mathrm{C}_{0}=3 \mathrm{pF}(-15 \mathrm{~K} \Omega), \mathrm{R}_{\mathrm{q}}=29 \Omega, \mathrm{C}_{\mathrm{q}}=23 \mathrm{fF}$ $(-2.0 \mathrm{M} \Omega), \mathrm{L}_{\mathrm{q}}=87 \mathrm{mH}(2.0 \mathrm{M} \Omega)$, and $\mathrm{C}_{3}=2.0 \mathrm{pF}(-23 \mathrm{~K} \Omega)$.

These values allow us to observe that: (1) the polyester film does not present a significant impedance when compared with the air-filled gap, thus the coating protects the brass electrode and does not disturb the circuit; (2) the gap filled with the salt solution used for our studies behaves mainly as a low-resistivity medium; and (3) the most important contribution to the impedance of the cell at the series resonance frequency is the air-filled gap. Thus, since the carrier solution keeps conductivity, viscosity, and density approximately constant, the frequency shift is mainly due to adsorption on the crystal surface.

Before modification, the response of the ESPC system for $\mathrm{Cu}^{2+}$ is practically null (Figure 5a). As shown in Figure $5 \mathrm{~b}$, the AEAPS group increases significantly the sensitivity. Due to the stability of the AEAPS/copper complex, the base line is not rapidly restored after the sample plug leaves the cell. In fact, the FIA system is viable only when an EDTA plug is injected after the sample. EDTA removes $\mathrm{Cu}^{2+}$ from the surface and quickly restores the base line. The measurements of the frequency $\operatorname{shift}(\Delta \mathrm{f})$ were made by subtracting the frequency before the injection and after the stabilization of the signal for each sample injection. The negative peak observed when the EDTA plug is injected could be associated to changes in the conductivity of the solution. When AEAPSmodified crystal is used, this effect is masked by the copper ions released from the surface.

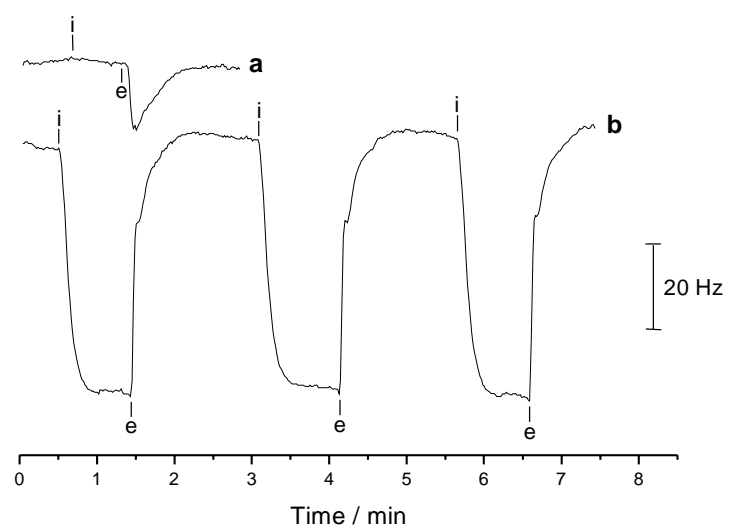

Figure 5. FIA response of the ESPC for injections of $0.6 \mathrm{mmol} \mathrm{L}^{-1} \mathrm{Cu}^{2+}$ solution, (a) non-silanized crystal, (b) silanized crystal with AEAPTS. Marks $i$ and e indicate the insertion moment of the sample and $50 \mathrm{mmol} \mathrm{L}^{-1}$ EDTA ( $\mathrm{pH} 8$ ) solutions, respectively, in the cell. Injection volume, $100 \mu \mathrm{L}$. Carrier solution, $0.1 \mathrm{~mol} \mathrm{~L}^{-1} \mathrm{KNO}_{3}$ ( $\mathrm{pH} 7$ ). Flow rate, $1.1 \mathrm{~mL} \mathrm{~min}^{-1}$.

The effect of the carrier solution $\mathrm{pH}$ is shown in Figure 6. For $\mathrm{pH}$ bellow 7, there is a lack of linearity at low copper concentration. Although the sensitivity is increased at $\mathrm{pH} 7$, there are two distinct regions in the analytical curve (Figure 6). For concentration below $0.6 \mathrm{mmol} \mathrm{L}^{-1}$, there is a linear region and above that value, there is a significant increasing of the slope and a new linear region rises. Thus, when necessary, the sample should be conveniently diluted to allow 


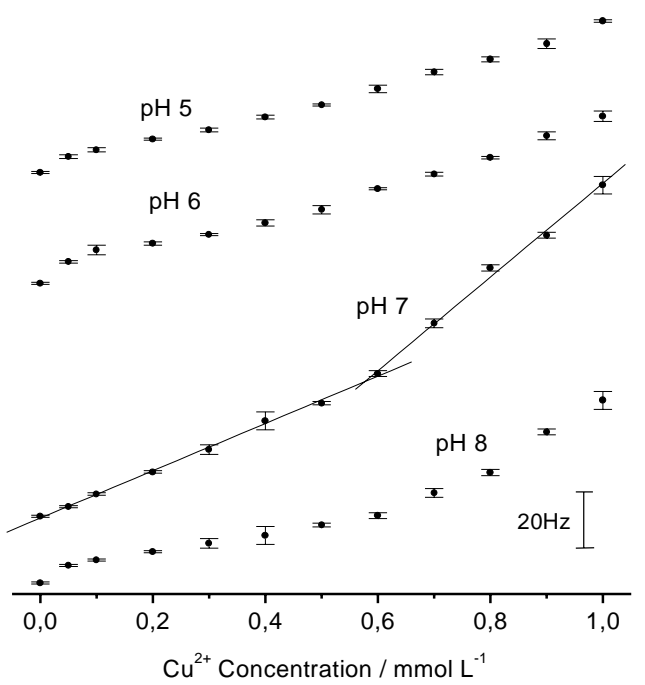

Figure 6. Dependence of frequency shift on the concentration of $\mathrm{Cu}(\mathrm{II})$ for different $\mathrm{pH}$ values of the carrier solution $\left(0.1 \mathrm{~mol} \mathrm{~L}^{-1} \mathrm{KNO}_{3}\right)$. The data sets were shifted by different frequency values in order to improve the visualization. The two straight lines over the set of points for $\mathrm{pH} 7$ experiment make clear the two nearly linear regions. Flow rate, 1.1 $\mathrm{mL} \min ^{-1}$. Injection volume, $100 \mu \mathrm{L}$

a linear region of the curve to be used. For $\mathrm{pH} 8$, same behavior was observed, but the sensitivity was lower.

The AEAPS group is protonated at low $\mathrm{pH}$ values; thus, it is not free to complex the metal ion. On the other hand, copper oxides and hydroxides hinder the complex formation at high $\mathrm{pH}$. The best observed $\mathrm{pH}$ was 7 , which gives a good compromise between metal cation and ligand availability. It is important to note that no buffer system has been used to prevent copper ions precipitation neither complex formation. Phosphate and citrate buffers reduce drastically the sensitivity. Of course, above $\mathrm{pH} 3$, even without other complexing species, hydroxides species of copper becomes predominant and, thus, any tentative explanation should consider the competition of the ligands for copper ions. Nevertheless, $\mathrm{KNO}_{3}$ solutions were used in order to emphasize the enhancement of sensitivity due to AEAPS group. On the other hand, the use of non-complexing buffers should be considered for real samples analyses.

Figure 7 shows the effect of the flow rate over the sensitivity for $\mathrm{Cu}^{2+}$. The sensitivity falls when the flow rate is increased, because the residence time of the sample plug in the cell determines the portion of the metal ions that will diffuse from the bulk of the solution to the crystal surface. Although low flow rate gives best sensitivity, it decreases the throughput of the analytical system. Thus, we chose $1.1 \mathrm{~mL} \mathrm{~min}^{-1}$ flow rate, which gives about 30 sample $^{-1}$, including the rinsing cycle with EDTA.

Solutions of $\mathrm{Zn}^{2+}, \mathrm{Mg}^{2+}, \mathrm{Ni}^{2+}$, and $\mathrm{Co}^{2+}$ were injected in the same system conditions, resulting in frequency shift lower than for $\mathrm{Cu}^{2+}$. This behaviour is still being investigated, but suggests that the film is fairly selective for $\mathrm{Cu}^{2+}$. Table 1 summarizes the limits of detection (three times the standard deviation of the base line) for the studied metal ions. These limits should be easily improved by substituting the $3.5-\mathrm{MHz}$ crystal by another with greater resonant frequency. This frequency increase would be also beneficial because of the

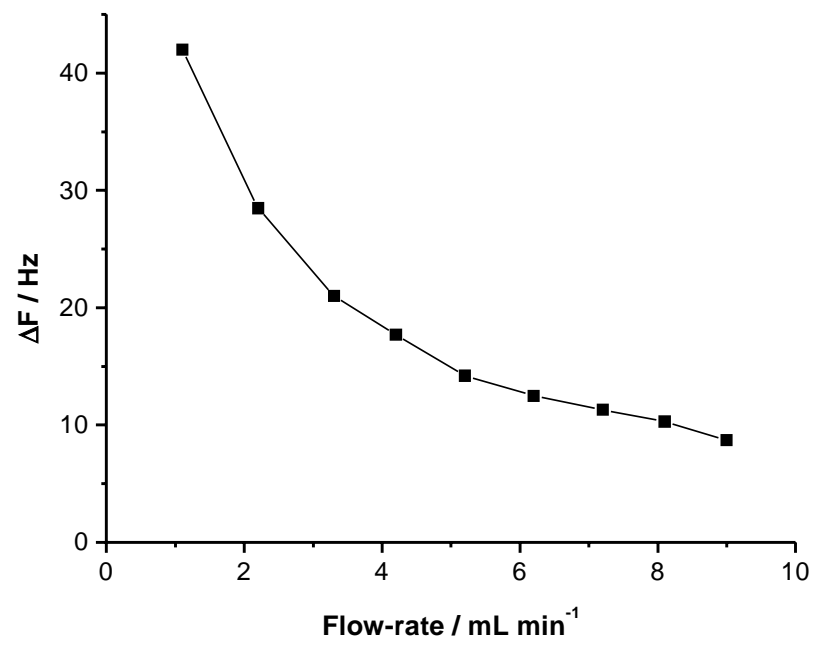

Figure 7. Influence of the flow rate on the frequency shift for $100 \mu \mathrm{L}$ injections of $0.5 \mathrm{mmol} \mathrm{L}^{-1} \mathrm{Cu}^{2+}$ solution.

Table 1. Limit of detection for some metal ions.

\begin{tabular}{lccccc}
\hline & $\mathrm{Cu}^{2+}$ & $\mathrm{Zn}^{2+}$ & $\mathrm{Mg}^{2+}$ & $\mathrm{Ni}^{2+}$ & $\mathrm{Co}^{2+}$ \\
\hline $\begin{array}{l}\text { Limit of detection / } \\
\text { mmol L-1 }\end{array}$ & 0.006 & 0.04 & 0.1 & 0.1 & 0.08
\end{tabular}

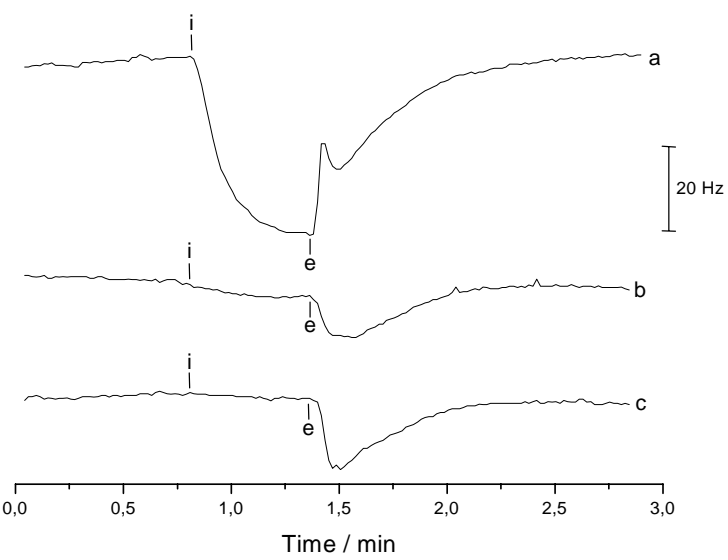

Figure 8. FIA response of the ESPC for injections of $\mathrm{Cu}^{2+}$ solutions (0.8 mmol L-1): (a) silanized crystal to be recycled, (b) the same crystal after soaking in $3 \mathrm{~mol} \mathrm{~L}^{-1} \mathrm{NaOH}$ for $30 \mathrm{~min}$, (c) the same crystal after an additional soaking in $3 \mathrm{~mol} \mathrm{~L}^{-1} \mathrm{NaOH}$ for $30 \mathrm{~min}$. Injection volume, $100 \mu \mathrm{L}$. Carrier solution, $0.1 \mathrm{~mol} \mathrm{~L}^{-1} \mathrm{KNO}_{3}(\mathrm{pH} 7)$. Marks $\mathbf{i}$ and $\mathbf{e}$ indicate the insertion moment of the sample and $50 \mathrm{mmol} \mathrm{L}^{-1}$ EDTA $(\mathrm{pH} 8)$ solutions, respectively, in the cell. Flow rate, $1.1 \mathrm{~mL} \mathrm{~min}^{-1}$. 
consequent increase of the cell admittance, which should simplify the circuitry.

An advantage of the present approach over other ESPC systems is the direct detection of the metal ions instead of hydroxides or insoluble complexes ${ }^{10-12}$. In those cases, precipitates are formed before the injection or in flow. The aging of the precipitated may cause problems of low reproducibility.

An important advantage of the free-of-electrode quartz surface is the possibility of restoring the crystal by removing of the silanized coating. Figure 8 a shows the fiagram for injection of a copper(II) solution in a cell with a modified crystal. This crystal was employed in a set of tests that reduce its performance. The crystal was then soaked in a 3 mol L-1 $\mathrm{NaOH}$ for $30 \mathrm{~min}$ and returned to the cell. Figure $8 \mathrm{~b}$ shows the reduction on the sensitivity after this procedure. Since the sensitivity was still greater than the one of an unmodified crystal, it was soaked again for 30 min. The signal in Figure 8c suggests that the regeneration procedure was effective.

\section{Conclusions}

The chemical modification results in a stable, sensitive, and fairly selective to copper(II) ions coating. Another advantage is the possibility of the surface renewal after signal decay by removing the old coating with sodium hydroxide and modifying the surface again with AEAPTS. The polymeric film that covers the electrode allows the use of non-noble metals, which reduces the cost of the system without loss of performance due to augmentation of impedance. On the other hand, the air gap between the non-used side of the crystal and the electrode represents an important contribution to the impedance of the cell and is a draw back that must be surpassed in the future. Based on these results, we conclude that the proposed ESPC system has some important features, which make the approach very promising.

\section{Acknowledgement}

This work was supported by Fundação de Amparo à Pesquisa do Estado de São Paulo (FAPESP) and Conselho Nacional de Desenvolvimento Científico e Tecnológico (CNPq). Authors thank FAPESP and CNPq for the research fellowships, National Semiconductor for the 74VHCU04N integrated circuit samples, and Mr. J. G. Richter for the English revision.

\section{References}

1. Slutsky,L. J.; Wade, W.H. J. Chem. Physics 1962, 36, 2688.

2. Nomura, T.; Yanagihara, T.; Mitsui, T. Anal. Chim. Acta 1991, 248, 329.

3. Mo,Z.; Nie, L.; Yao, S. J. Electroanal. Chem. 1991, 316, 79.

4. Zhu, W.; Wei, W.; Nie, L.; Yao, S. Anal. Chim. Acta 1993, 282, 535.

5. Zhu, W.; Wei, W.; Mo, Z.; Nie, L.; Yao, S. Anal. Chem. 1993, 65, 2568.

6. Dazhong, S.; Song, L.; Qi, K.; Nie, L.; Yao, S. Analyst 1993, 118, 1143.

7. Takada, K.; Tatsuma, T.; Oyama, N.; Nomura, T. J. Electroanal. Chem. 1994, 370, 103.

8. Shen, D.; Huang, M., Nie, L.; Yao, S. J. Electroanal. Chem. 1994, 371, 117.

9. Xu, Y.; Shen, D.; Xie, Q.; Nie, L.; Yao, S. J. Electroanal. Chem. 1995, 387, 23.

10. Nomura, T.; Isawa, M.; Matsuzawa, H.; Shibukawa, Y. Anal. Chim. Acta 1994, 286, 205.

11. Nomura, T.; Egawa, T. Anal. Chim. Acta 1997, 339, 187.

12. Nomura, T.; Kumagai, M.; Sato, A. Anal. Chim. Acta 1997, 343, 209.

13. Dazhong, S.; Songmin, P.; Qi, K.; Yanhui, X. Fresenius J. Anal. Chem. 1998, 361, 424.

14. Shen, D. Z.; Xue, Y. H.; Kang, Q.; Xie, Q. J.; Chen, L. X. Microchemical J. 1998, 60, 1.

15. Nomura, T.; Sato, A. Anal. Chim. Acta 1998, 374, 291.

16. Dazhong, S.; Qingji, X.; Qi, K.; Yanhui, X. Mikrochim. Acta 1998, 128, 229.

17. He, F.; Deng, L.; Xie, Q.; Nie, L.; Yao, S. Anal. Letters 1995, 28, 213.

18. Muramatsu, T.; Dicks, J. M.; Tamiya, E.; Karube, I. Anal. Chem. 1987, 59, 2760.

19. Cavic-Vlasak, B. A.; Rajakovic, L. J. Fresenius J. Anal. Chem. 1992, 342, 339.

20. König, B.; Grätzel, M. Anal. Letters 1993, 26, 1567.

21. Minunni, M.; Skládal, P.; Mascini, M. Anal. Letters 1994, 27, 1475.

22. Suri, C. R.; Mishra, G. C. Biosen. \& Bioelectr. 1996, $11,1199$.

23. Horácek, J.; Skládal, P. Anal. Chim. Acta 1997, 347, 43.

24. Chance, J. J.; Purdy, W. C. Thin Solids Films 1998, 335, 237.

25. Ricco, A. J.; Martin, S. J.; Niemczyk, T. M.; Frye, G. C. ACS Symposium Series 1989, 403, 191.

26. Kanazawa, K. K.; Gordon II, J. G. Anal. Chim. Acta 1985, $175,99$.

Received: July, 5, 2000

Published on the web: January 15, 2001

FAPESP helped in meeting the publication costs of this article. 